\title{
FERMENTASI DENGAN MENGGUNAKAN BERBAGAI JENIS MIKROBIA UNTUK MENURUNKAN KANDUNGAN SAPONIN BUAH TREMBESI (SAMMANEA SAMAN)
}

\author{
Ahimsa Kandi Sariri, Engkus Ainul Yakin \\ Program studi Peternakan FP Univet Bantara Sukoharjo Jl. Letjen S. Humardani No 1 \\ Sukoharjo, kode pos 57512, Telp. (0271)593156, Fax (0271)591065, \\ Email ak sariri@ymail.com
}

\begin{abstract}
Abstrak
Penelitian ini bertujuan untuk mengetahui pengaruh fermentasi dengan menggunakan berbagai mikrobia terhadap kandungan saponin dan nutrient buah trembesi. Agensia fermentasi yang digunakan terdiri dari dua kelompok yaitu jamur Aspergillus niger dan bakteri Lactobacillus plantarum. Rancangan yang digunakan adalah Rancangan Acak Lengkap pola searah perlakuan diulang sebanyak 3 kali sehingga terbentuk kombinasi perlakuan 12 unit percobaan. Analisis yang dilakukan meliputi analisis kandungan saponin dan analisis proksimat daun trembesi. Penelitian ini dapat disimpulkan bahwa penggunaan Aspergillus niger dan Lactobacillus plantarum dalam fermentasi dapat menurunkan kandungan saponin dalam buah trembesi dan penggunaan Aspergillus niger dan Lactobacillus plantarum dalam fermentasi dapat menurunkan kandungan kandungan serat kasar dan meningkatkan protein kasar buah trembesi.
\end{abstract}

Kata kunci : buah trembesi, fermentasi, saponin,

Fermentation by Using Different Types of Microbes for Decreased Saponin Content in Fruit of Trembesi (Sammanea saman)

\begin{abstract}
This objectives research to effect of using different microbial fermentation in reducing the saponin content while increasing the nutrient content in trembesi pods (Sammanea saman). Fermentation agents used consisted of two groups: the fungus is Aspergillus niger and bacteria is Lactobacillus plantarum. The design used was completely randomized design pattern in the direction of the treatment repeated six times to form the combined treatment of 12 experimental units. Analysis was conducted on the saponin content analysis and proximate analysis of trembesi pods This study concluded that the use of Aspergillus niger and Lactobacillus plantarum in the fermentation can reduced the saponin content of the trembesi pods and use of Aspergillus niger and Lactobacillus plantarum in the fermentation can reduce the content of crude fiber content and increasing the crude protein trembesi pods.
\end{abstract}

Keywords : fermentation, saponin, trembesi

\section{PENDAHULUAN}

Pohon trembesi adalah pohon yang memiliki kemampuan menyerap air tanah yang kuat, dapat menyerap 28,5 ton/tahun karbondioksida dan mempunyai perakaran yang dapat bersimbiosis dengan bakteri rhizobium untuk mengikat nitrogen dari udara. Sebaliknya banyak riset menyatakan bahwa trembesi termasuk jenis pohon dengan evaporasi atau penguapan tinggi sehingga berpotensi mengeringkan sumber air selain itu juga merupakan pohon yang mempunyai perakaran yang dangkal sehingga pohon ini mudah roboh selain itu trembesi bersifat invasif karena memiliki tajuk yang luas, sekaligus tebal. Kondisi ini membuat cahaya matahari sulit menembus. tanaman di bawah naungan tajuknya sehingga tidak bisa tumbuh subur, bahkan mati. 
Trembesi telah dimanfaatkan oelh masyarakat. Buah trembesi menjadi makanan ringan bagi manusia. Daun dan kulit buah trembesi digunakan sebagai pakan ternak ruminansia. Ternak ruminansia adalah ternak yang mempunyai lambung jamak dengan empat kompartemen dan mengalami proses ruminasi. Keberlangsungan proses ruminasi sangat tergantung dengan adanya bahan pakan yang mempunyai kandungan serat kasar tinggi. Bahan pakan dengan kandungan serat kasar yang tinggi banyak terdapat pada hijauan tanaman. Ketersediaan hijauan pakan di Indonesia tidak terjamin. Pada musim penghujan hijauan berlimpah tetapi pada saat musim kemarau sangat kurang . Ketidaktersediaannya hijauan pakan sebagai kebutuhan pokok ternak ruminansia, memaksa peternak untuk memberikan hijauan pakan seadanya yang biasanya diperoleh dari tanaman tahunan.

Trembesi masuk dalam familia Mimosoideae. Daun, biji, dan kulit batang trembesi mengandung saponin disamping itu daun dan bijinya mengandung polifenol. (Mc Donald et al., 1988). Lebih lanjut Widodo (2005) menyatakan saponin ada pada seluruh bagian tanaman, misalnya pada daun, batang, akar, bunga dan biji sedangkan jumlahnya bervariasi sesuai waktu pemotongan. tetapi di sisi lain tanaman ini mempunyai perakaran yang dapat bersimbiosis dengan bakteri rhizobium yang bisa mengikat $\mathrm{N}$ bebas

Saponin adalah glikosida yang setelah dihidrolisis akan menghasilkan gula (glikon) dan sapogenin (aglikon). Senyawa aktif permukaan dari saponin bersifat seperti sabun dan dideteksi berdasarkan kemampuan membentuk busa pada pengocokan dan memiliki rasa pahit yang mempunyai efek menurunkan tegangan permukaan sehingga merusak membran sel dan menginaktifkan enzim sel serta merusak protein sel (Hostettmann, 1995).

Saponin dapat memberikan pengaruh terhadap proses biologis tubuh dan metabolisme zat nutrisi dengan cara menghambat produktivitas kerja enzim seperti enzim kimotripsin sehingga menghambat produktivitas dan pertumbuhan ternak. Efek biologis utama dari saponin adalah saponin mampu menghemolisis sel darah merah karena interaksi saponin dengan membran (protein, fosfolipida dan kolesterol) dari eritrosit. Hemolisis adalah terlepasnya hemoglobin ke dalam plasma darah akibat pemecahan eritrosit ( Francis et al., 2002).

Pakan yang mengandung lebih dari $0,20 \%$ saponin akan berakibat buruk terhadap pertumbuhan, konsumsi pakan dan efisiensi pakan. Saponin pada alfalfa dapat mengakibatkan kembung pada ruminansia karena saponin merupakan agen-agen aktif pada permukaannya dalam memproduksi sabun yang bersifat membusa. Level rendah penggunaan tepung alfalfa menurunkan jumlah rata-rata pertumbuhan unggas, yang menjadi efek utama dari kandungan saponin adalah pada palatabilitas dan feed intake dibandingkan pada efek metabolismenya. Penggunaan strain rendah saponin meningkatkan level alfalfa menjadi bahan makanan untuk ruminansi tanpa menurunkan penampilan pertumbuhannya ( Francis et al., 2002).

Fermentasi adalah proses pemecahan karbohidrat menjadi alkohol, asam laktat, asam butirat dan asam karbonat serta pelepasan panas. Protein dirombak menjadi amonia, asam amino, amida, asam asetat, asam butirat dan air. Suliantari dan Rahayu (1990) menyatakan bahwa dengan fermentasi terjadi penghilangan zat anti nutrisi yang bersifat racun antara lain glukosida. Selanjutnya fermentasi daun ubikayu dengan Aspergillus 
Sariri, AK \& Yakin, EA. 2019

Agrisaintifika

Jurnal Ilmu-Ilmu Pertanian

Vol. 3, No. 2, 2019

niger mampu meningkatkan protein, nilai kecernaan dan penurunan serat kasar (Balitnak, 1994).

\section{BAHAN DAN METODE}

Penelitian dilakukan di Laboratorium Biologi, Kimia dan Mikrobiologi Fakultas Pertanian Universitas Veteran Bangun Nusantara Sukoharjo. Analisis proksimat dan saponin dilakukan di Laboratorium Kimia Analitik Universitas Gadjah Mada Yogyakarta. Materi yang digunakan adalah :

\section{Substrat}

Substrat yang digunakan adalah buah trembesi yang terdiri dari kulit dan biji. Buah trembesi yang digunakan diambil dari tiga tanaman trembesi yang tumbuh di Desa Munggur Kecamatan/Kabupaten Karanganyar yang sering digunakan oleh peternak sebagai pakan ternak.

Agensia Fermentasi

Agensia fermentasi yang digunakan terdiri dari dua kelompok yaitu jamur : Aspergillus niger dan bakteri : Lactobacillus plantarum.

\section{Rancangan Percobaan}

Penelitian ini dirancang dengan Rancangan Acak Lengkap pola searah dengan perlakuan penambahan agensia fermentasi Aspergillus niger dan bakteri : Lactobacillus plantarum. Setiap perlakuan diulang sebanyak tiga kali sehingga terbentuk kombinasi perlakuan 12 unit percobaan.

\section{Pelaksanaan Penelitian}

A.5.1. Preparasi agensia fermentasi :

1. Perbanyakan isolat

2. Menumbuhkan agensia, untuk A.niger dalam media potato dekstrose sedangkan L.plantarum dalam media MRS

3. Inkubasi

A.5.2. Preparasi buah trembesi :
1. Buah trembesi diambil dari pohon kemudian dipisahkan antara kulit dan bijinya.

2. Kulit dan biji trembesi kemudian dibungkus koran untuk menahan respirasi sel selama pengangkutan.

3. Untuk menunggu pelaksanaan fermentasi, kulit dan biji trembesi yang dibungkus koran disimpan dalam lemari pendingin.

A.5.3. Fermentasi

1. Kulit dan biji trembesi yang dibungkus, dibuka kembali dan dicampur dengan urea kemudian diaduk hingga merata. Setelah itu kulit trembesi dikelompokkan menjadi 6 kelompok dan biji trembesi dikelompokkan menjadi 6 sehingga ada 12 kelompok yang kemudian menjadi unit percobaan.

2. Dari 6 unit percobaan kulit trembesi dibagi menjadi dua. 3 unit percobaan diberi A.niger dan 3 unit percobaan diberi L.plantarum. Kemudian dicampur hingga merata. 6 unit percobaan biji trembesi juga dibagi menjadi dua. 3 unit percobaan diberi A.niger dan 3 unit percobaan diberi L.plantarum. Kemudian dicampur hingga merata.

3. Semua unit percobaan, masing-masing dimasukkan ke dalam plastik dan ditekan sedemikian rupa sehingga diusahakan tertutup rapat.

4. Peram selama 21 hari.

\section{Analisis kandungan nutrien dan analisis kandungan saponin.}

Daun trembesi sebelum dan sesudah fermentasi dilakukan analisis kandungan nutrien yang meliputi bahan kering, kandungan air, protein kasar, lemak kasar, serat kasar, abu dengan menggunakan analisis proksimat (AOAC, 1990) dan kandungan saponin dengan analisis saponin. 


\section{Analisis Statistik}

Data yang diperoleh dianalisis dengan menggunakan rancangan acak lengkap (RAL) pola seaarah. Bagi variable yang menunjukkan pengaruh yang nyata $(P<0,05)$ maka diuji lanjut dengan Duncan's Multiple Range Test (DMRT) pada taraf $5 \%$ (Astuti, 1980).

\section{HASIL DAN PEMBAHASAN}

Penelitian ini bertujuan untuk mengetahui peningkatan kandungan nutrien dan penurunan saponin dalam trembesi yang difermentasi dengan penambahan mikrobia yang berbeda yaitu Aspergillus niger dan Lactobacillus plantarum. Kandungan nutrien dan saponin pada trembesi sebelum difermentasi dapat dilihat pada Tabel 1 . Setelah mengetahui kandungan nutrien dan saponin dalam trembesi maka dilakukan fermentasi. Dalam fermentasi tersebut digunakan dua jenis mikrobia yang akan dipilih mikrobia yang paling memberikan peningkatan nutrien dan menurunkan kandungan saponin buah trembesi. Hasil fermentasi trembesi dengan penambahan mikrobia dapat dilihat pada Tabel 2.

\section{Kandungan Nutrien}

Kadar Air

Hasil penelitian menunjukkan bahwa terjadi peningkatan kadar air pada trembesi yang difermentasi dengan Aspergillus niger ataupun Lactobacillus plantarum dibandingkan dengan tanpa fermentasi. Hal ini bisa diakibatkan karena aktivitas Aspergillus niger dan Lactobacillus plantarum akan menghasilkan asam. Aspergillus niger menghasilkan asam sitrat dan Lactobacillus plantarum akan menghasilkan asam laktat. Dengan keadaan asam akan menghambat aktivitas mikroorganisme dalam penguraian karbohidrat dan protein yang hasil sampingannya adalah uap air.

Dari Tabel 2. Menunjukkan bahwa penambahan mikrobia dalam fermentasi kulit buah trembesi dapat meningkatkan kadar air secara nyata dibandingkan kadar air buah muda trembesi. Hal ini bisa diakibatkan oleh kadar air kulit buah trembesi yang memang lebih tinggi daripada buah muda trembesi. Selain itu bisa diakibatkan karena kulit buah mempunyai tekstur yang lebih tebal daripada buah muda, dilain pihak bahwa tanaman banyak mengandung selulosa, hemiselulosa dan lignin. Kulit buah dimungkinkan lebih banyak mengandung selulosa dan hemiselulosa yang merupakan karbohidrat seperti yang tertera di Tabel 1. Fermentasi karbohidrat akan menghasilkan asam dan hasil sampingan air. Dengan semakin banyak karbohidrat yang dirombak oleh mikrobia maka akan semakin tinggi pula air yang dihasilkan.

\section{Abu}

Perlakuan penambahan mikrobia dalam fermentasi ternyata dapat meningkatkan kandungan abu pada trembesi. Peningkatan kandungan abu merupakan indikasi terjadi peningkatan kandungan mineral pada trembesi.

Dari Tabel 2. Menunjukkan bahwa penambahan Aspergillus niger dan Lactobacillus plantarum dalam fermentasi trembesi tidak mempengaruhi secara nyata peningkatan kandungan abu pada buah muda dan kulit buah trembesi terfermentasi.

Kandungan abu pada buah muda dan kulit buah tidak berbeda nyata, tetapi kulit buah mempunyai kandungan abu yang lebih tinggi dibandingkan buah muda. Hal ini menunjukkan bahwa kulit buah trembesi mempunyai kandungan mineral yang lebih tinggi dibandingkan dengan buah muda. 
Tabel 1. Kandungan Nutrien dan Saponin Trembesi

\begin{tabular}{ccccccc}
\hline $\begin{array}{c}\text { Bagian } \\
\text { Tanaman }\end{array}$ & KA & Abu & LK & PK & KH & Saponin \\
\hline Buah Muda & 52,73 & 3,82 & 0,29 & 11,81 & 43,87 & 0,95 \\
Kulit Buah & 54,35 & 3,94 & 0,08 & 8,32 & 77,28 & 1,44 \\
\hline
\end{tabular}

Tabel 2. Kandungan nutrien dan saponin Trembesi Terfermentasi

\begin{tabular}{lrrrrrr}
\hline $\begin{array}{c}\text { Materi } \\
\text { Penelitian }\end{array}$ & KA & Abu & LK & PK & KH & Saponin \\
\hline B-An & $59.14^{\mathrm{a}}$ & $4.44^{\mathrm{a}}$ & $5.21^{\mathrm{b}}$ & $42.58^{\mathrm{b}}$ & $38.27^{\mathrm{a}}$ & $0.06^{\mathrm{a}}$ \\
K-An & $60.48^{\mathrm{b}}$ & $4.73^{\mathrm{a}}$ & $1.50^{\mathrm{a}}$ & $22.54^{\mathrm{a}}$ & $60.92^{\mathrm{b}}$ & $0.92^{\mathrm{b}}$ \\
B-Lp & $59.10^{\mathrm{a}}$ & $4.31^{\mathrm{a}}$ & $5.18^{\mathrm{b}}$ & $48.16^{\mathrm{b}}$ & $33.25^{\mathrm{a}}$ & $0.08^{\mathrm{a}}$ \\
K-Lp & $60.58^{\mathrm{b}}$ & $4.88^{\mathrm{a}}$ & $1.57^{\mathrm{a}}$ & $59.79^{\mathrm{c}}$ & $59.79^{\mathrm{b}}$ & $0.89^{\mathrm{b}}$ \\
\hline
\end{tabular}

\section{Lemak}

Kandungan lemak kasar trembesi mengalami peningkatan setelah difermentasi dengan penambahan mikrobia didalamnya. Lemak dalam tanaman lebih banyak yang merupakan lemak sederhana (Widodo, 2005). Lemak adalah kelompok senyawa heterogen yang berkaitan baik secara aktual maupun potensial dengan asam lemak. Didalam tubuh, lemak berfungsi sebagai sumber energi yang efisien secara langsung dan potensial bila disimpan dalam jaringan adiposa.

Dari Tabel 2. Menunjukkan bahwa penambahan mikrobia tidak mempengaruhi peningkatan kandungan lemak kasar trembesi secara nyata, tetapi penambahan mikrobia dalam fermentasi buah muda trembesi dapat meningkatkan kandungan lemak kasar secara nyata dibandingkan kandungan lemak kasar pada kulit buah trembesi.

Lemak pada tanamana biasanya merupakan lemak sederhana. Lemak sederhana adalah ester asam lemak dengan berbagai alkohol. Lemak sederhana terdiri dari lemak dan lilin (Widodo,2005). Hal ini menunjukkan bahwa kandungan lemak dan lilin dalam buah muda lebih tinggi dibandingkan dengan kulit buah.

\section{Protein}

Perlakuan fermentasi ternyata memberikan peningkatan kandungan protein kasar yang cukup besar pada trembesi. Penambahan mikrobia Aspergillus niger dan Lactobacillus plantarum dalam fermentasi juga efektif dalam meningkatkan kandungan protein kasar trembesi.

Dari Tabel 2. Menunjukkan bahwa penambahan mikrobia Aspergillus niger dapat meningkatkan kandungan protein kasar buah muda berbeda secara nyata dibandingkan dengan kandungan protein kasar kulit buah trembesi. Penambahan Lactobacillus plantarum ternyata lebih bisa meningkatkan protein kasar yang cukup besar pada kulit buah dan buah muda trembesi.

Kandungan protein dalam pakan akan meningkatkan palatabilitas pakan tersebut. Dengan palatabilitas yang tinggi maka akan meningkatkan konsumsi ternak pada pakan 
tersebut, yang akhirnya diharapkan dapat meningkatkan produksitivitas ternak.

Lactobacillus plantarum lebih efektif dalam meningkatkan kandungan protein kasar pada trembesi dibandingkan dengan Aspergillus niger, hal ini bisa diakibatkan karena bakteri Lactobacillus plantarum merupakan bakteri penghasil asam laktat yang juga menghasilkan bakteriosin. Bakteriosin merupakan senyawa protein yang bersifat bakterisidal (James et al., 1992 dalam Afriani, 2010).

\section{Karbohidrat}

Karbohidrat trembesi terfermentasi menurun dibandingkan dengan trembesi yang tidak difermentasi. Karbohidrat dalam suatu bahan terdiri dari serat kasar dan ekstrak tanpa nitrogen. Walaupun bukan suatu kepastian tetapi penurunan karbohidrat bisa merupakan indikasi dari penurunan serat kasar.

Tabel 2. Menunjukkan bahwa Aspergillus niger dan Lactobacillus plantarum memberikan kandungan karbohidrat kasar pada kulit buah lebih besar secara nyata dibandingkan kandungan karbohidrat kasar pada buah muda. Hal ini bisa diakibatkan bahwa buah muda suatu tanaman banyak mengandung protein dibandingkan dengan karbohidrat dan lipid (Dwidjoseputro, 1991).

Karbohidrat akan memberikan kontribusi sebagai sumber energi dalam suatu ransum pakan ternak. Melihat Tabel 1 dan Tabel 2. Bisa dikatakan bahwa dengan fermentasi yang menggunakan Aspergillus niger dan Lactobacillus plantarum dapat menurunkan kandungan karbohidrat kasar trembesi tetapi masih mempertahankan karbohidrat kasar dalam keadaan di cukup tinggi pada kulit buah. Diharapkan yang diturunkan pada fermentasi tersebut adalah serat kasarnya. Pakan dengan serat kasar yang rendah akan meningkatkan nilai kecernaan suatu pakan (Tillman et al., 1984).

\section{Kandungan Saponin}

Kandungan saponin trembesi menurun dengan perlakuan fermentasi yang menggunakan mikrobia baik Aspergillus niger ataupun Lactobacillus plantarum. Hal ini sesuai dengan pendapat Suliantari dan Rahayu (1990) yang menyatakan bahwa dengan fermentasi terjadi penghilangan zat anti nutrisi yang bersifat racun antara lain glukosida. Widodo (2005) menyatakan bahwa saponin merupakan suatu glikosida, apabila dihidrolisis maka menghasilkan gula (glikon) dan sapogenin (aglikon).

Tabel 2. Menunjukkan bahwa kandungan saponin buah muda berbeda nyata dengan kandungan saponin kulit buah trembesi. Kandungan saponin pada kulit buah trembesi yang difermentasi dengan Lactobacillus plantarum lebih rendah dibandingkan dengan yang difermentasi dengan aspergillus niger. Hal ini bisa diakibatkan karena Lactobacillus plantarum merupakan bakteri asam laktat, yaitu bakteri yang mengubah laktosa dan gula lainnya menjadi asam laktat. Laktosa dan gula lainnya masuk dalam golongan karbohidrat. Trembesi mempunyai kandungan karbohidrat yang cukup tinggi sehingga bisa lebih mengefektifkan kerja Lactobacillus plantarum dibandingan Aspergillus niger. Mempunyai kemampuan untuk menghasilkan bakteriosin yang berfungsi sebagai zat antibiotik (Jenie dan Rini, 1995 dalam Taufik, 2004).

\section{KESIMPULAN}

Penggunaan Aspergillus niger dan Lactobacillus plantarum dalam fermentasi dapat menurunkan kandungan saponin dalam buah trembesi dan dapat meningkatkan kandungan nutrien buah trembesi dengan peningkatan kandungan protein kasar 
sebaliknya menurunkan kandungan serat kasar buah trembesi.

\section{DAFTAR PUSTAKA}

Afriani. 2010. Pengaruh Penggunaan Starter Bakteri Asam Laktat Lactobacillus plantarum dan Laktobacillus fermentum terhadap Total Bakteri Asam Laktat, Kadar Asam, dan Nilai pH Dadih Susu Sapi. Jurnal IImiah IImu-IImu Peternakan. Volume XIII No. 6.

Astuti, Maria. 1980. Rancangan Percobaan. Universitas Gadjah Mada Press. Yogyakarta.

Balitnak, 1994. Pemanfaatan Limbah Pertanian dan Limbah Pengolahan Tapioka/Sagu sebagai Pakan Ternak. Warta Penelitian Dan Pengembangan Pertanian.

Dwidjoseputro,D. 1990. Pengantar Fisiologi Tumbuhan. PT. Gramedia Pustaka Utama. Jakarta.

Francis, George; Zohar Kerem, Harinder P. S. Makkar and Klaus Becker (December 2002). "The biological action of saponins in animal systems: a review". British Journal of Nutrition 88 (6): 587-605. doi:10.1079/BJN2002725. $\quad$ PMID $\underline{12493081}$

Hostettmann, K.; A. Marston (1995). Saponins. Cambridge: Cambridge University Press. p. 3ff. ISBN 0-521-32970-1. OCLC $\underline{29670810}$
McDonald, P., R.A. Edwards, and J.F.D. Greenhalgh. 1988. Animal Nutrition. 4 edition. Longman Scientific \& Technical. England.

Sariri, A.K., 2012. Fermentasi dengan Menggunakan Berbagai Jenis Mikrobia untukMenurunkan Kandungan Saponin Daun Trembesi (Sammanea saman). Laporan Penelitian Kompetitif. Universitas Veteran Bangun Nusantara Sukoharjo.

Soejono, Mohammad. 2004. Petunjuk Laboratorium Analisis dan Evaluasi Pakan. Laboratorium Teknologi Makanan Ternak Jurusan NMT fakultas Peternakan UGM. Yogyakarta..

Suliantari dan W.P. Rahayu. 1990. Teknologi Fermentasi Biji-bijian dan Umbi-umbian. PAU-IPB. Bogor.

Taufik, E. 2004. Dadih Susu Sapi Hasil Fermentasi berbagai Starter Bakteri Probiotik yang Disimpan pada Suhu Rendah. Media Peternakan. 27(3): 88133.

Tillman, Allen D., Hari H, Soedomo R, Soeharto P, P. Soekanto L. 1984. IImu Makanan Ternak Dasar. UGM Press. Yogyakarta.

Widodo, Wahyu. 2005. Tanaman Beracun dalam Kehidupan Ternak. UMM Press. Malang. 